\title{
Assessment of the safety of hydrogenated resistant maltodextrin: reverse mutation assay, acute and 90-day subchronic repeated oral toxicity in rats, and acute no-effect level for diarrhea in humans
}

\author{
Yuko Yoshikawa, Yuka Kishimoto, Hiroyuki Tagami and Sumiko Kanahori \\ Research Laboratory, Matsutani Chemical Industry Co., Ltd., 5-3 Kita-itami, Itami City, \\ Hyogo, 664-8508, Japan
}

(Received January 9, 2013; Accepted March 26, 2013)

\begin{abstract}
A series of safety assessments were performed on hydrogenated resistant maltodextrin prepared by converting the reducing terminal glucose of resistant maltodextrin into sorbitol. The reverse mutation assay did not show mutagenicity. Acute and 90 -day subchronic oral toxicity studies in rats showed no death was observed in any groups, including the group receiving the highest single dose of $10 \mathrm{~g} / \mathrm{kg}$ body weight or the highest dose of $5 \mathrm{~g} / \mathrm{kg}$ body weight per day for 90 days. Mucous or watery stools were observed in the hydrogenated resistant maltodextrin treatment group on the acute study, which were transient and were associated with the osmotic pressure caused by intake of the high concentrations. Subchronic study showed dose-dependent increases in the weights of cecum alone, cecal contents alone, and cecum with cecal contents as well as hypertrophy of the cecal mucosal epithelium, which are considered to be common physiological responses after intake of indigestible carbohydrates. These results indicated that the no observed adverse effect level (NOAEL) of hydrogenated resistant maltodextrin was $10 \mathrm{~g} / \mathrm{kg}$ body weight or more on the acute oral toxicity study and $5.0 \mathrm{~g} / \mathrm{kg}$ body weight $/$ day or more on the 90-day subchronic repeated oral toxicity study in rats. Further study performed in healthy adult humans showed that the acute no-effect level of hydrogenated resistant maltodextrin for diarrhea was $0.8 \mathrm{~g} / \mathrm{kg}$ body weight for men and more than $1.0 \mathrm{~g} / \mathrm{kg}$ body weight for women. The results of the current safety assessment studies suggest that hydrogenated resistant maltodextrin is safe for human consumption.
\end{abstract}

Key words: Hydrogenated resistant maltodextrin, Reverse mutation assay, Acute toxicity, Subchronic toxicity, Acute no-effect level for diarrhea

\section{INTRODUCTION}

Resistant maltodextrin (Fibersol-2; FS-2) is a watersoluble dietary fiber. FS-2 is commonly used as a dietary fiber ingredient for a wide variety of processed food products because of its low viscosity, low sweetness, and high stability against acid, heat, and other parameters involved in food processing.

The process of manufacturing FS-2 includes starch roasting, and the product remains slightly yellowish in color after a purification process using ion exchange resins and active carbon. In addition, FS-2 can occasionally become brownish during storage under certain conditions, which continues to be a concern for utilizing FS-2 in a clear beverage or white food products, where coloration or browning reaction are unacceptable to food manufacturers. Browning occurs over a period mostly by the Maillard reaction between the reducing terminal glucose of FS-2 and amino acids or protein from other ingredients. Therefore, hydrogenated resistant maltodextrin (Fibersol-2H; FS-2H) was produced by converting the reducing terminal glucose into sorbitol through hydrogenation.

Numerous studies performed to determine the safety of FS-2 have shown that FS-2 is nonmutagenic, and the safety of FS-2 has been confirmed in acute and subchronic toxicity studies in rats as well as in the excessive intake study in humans (Satouchi et al., 1993; Wakabayashi et

Correspondence: Yuko Yoshikawa (E-mail: yuko-yoshikawa@matsutani.co.jp) 
al., 1991, 1992). No adverse event was observed in the subchronic study in humans, and FS-2 actually has been added to various categories of food products, including many functional foods and beverages known as "Foods for Specified Health Use" in the Japanese market (Fuse et al., 2002; Kishimoto et al., 2000; Nakagawa et al., 2003; Yuasa et al., 2004). In the United States, FS-2 is generally recognized as safe (GRAS) and has been used in various food and beverage products. No difference is observed between FS-2 and FS-2H in terms of the dietary fiber content, osmotic pressure of aqueous solution, etc. (Hayashi et al., 2006). These results suggest that hydrogenation of FS-2 does not alter the basic physical properties and does not cause any decomposition or condensation in structure. Furthermore, we performed some studies to confirm that FS-2H has properties similar to those of FS-2, such as resistance to digestive enzymes, fermentability by microflora in the large intestine, and excretion rate into feces (Tagami et al., 2012), which suggest that the effect of FS-2H on gastrointestinal symptoms and diarrhea would be similar to that of FS-2. In fact, a study on excessive intake of FS-2H in humans, $11 \mathrm{~g}$ of FS-2H in a $500 \mathrm{ml}$ soft drink 3 times a day for 4 weeks, showed no clinically significant adverse event (Hamano et al., 2004). Another study showed no clinically significant adverse event when patients with diabetes mellitus and borderline diabetic patients consumed low-protein rice containing $7.5 \mathrm{~g}$ FS$2 \mathrm{H}$ twice or 3 times per day for 12 weeks (Osada et al., 2011). Thus, FS-2H is considered as a highly safe food ingredient. However, no studies have reported the toxicological profile of FS-2H, and no studies have reported the acute no-effect single-dose level of FS-2H for diarrhea in humans. In this study, we performed a reverse mutagenicity study, an acute, and a 90-day oral toxicity study of FS$2 \mathrm{H}$ in rats. Additionally, we performed an acute study of FS-2H in healthy adult humans to estimate the acute noeffect level for diarrhea.

\section{MATERIALS AND METHODS}

\section{Test substance}

The test substance FS-2H (Fibersol-2H; Matsutani Chemical Industry Co., Ltd., Hyogo, Japan) is prepared by hydrogenation of FS-2 (Fibersol-2; Matsutani Chemical Industry Co., Ltd.). The dietary fiber content of the FS-2H sample measured using Enzyme-HPLC method (AOAC 2001.03) was $89.1 \%$ for the 90 -day subchronic repeated oral toxicity study in rats and $87.0 \%$ for the rest of experiments.

\section{Reverse mutation assay (Ames test)}

The test bacterial strains were Salmonella typhimurium TA98, TA100, TA1537, and TA1535 obtained from the Toxicology Department, The Institute of Environmental Toxicology (Ibaraki, Japan) and Escherichia coli WP2uvrA obtained from Japan Bioassay Research Center (Kanagawa, Japan). S9 fraction and Cofactor-I were purchased from Oriental Yeast Co., Ltd. (Tokyo, Japan), and the S9 mix was prepared just before use for metabolic activation. The dose levels of FS-2H were 313,625 , 1250,2500 , and $5000 \mu \mathrm{g} /$ plate. Distilled water was used as the negative control. Incubation and colony counting were performed using the common procedure. The positive controls 2-(2-furyl)-3-(5-nitro-2-furyl)acrylamide (AF-2), sodium azide (SAZ), and2-aminoanthracene(2AA) were purchased from Wako Pure Chemical Industries, Ltd. (Osaka, Japan), and 9-aminoacridine (9AA) was purchased from Aldrich Chemical Company, Inc. (Milwaukee, WI, USA). The concentrations of the positive controls were set in accordance with the "Mutation Test Pursuant to the Industrial Safety and Health Act-Test Guidelines and GLP" (Chemical Substances Investigation Division, Industrial Safety and Health Department, Labor Standard Bureau, Ministry of Labor) (Table 1). Samples were determined as positive if the number of reverse mutation colonies was twice or more than that of the negative con-

Table 1. Concentration of chemical substance for positive control used in the FS-2H reverse mutation assay.

\begin{tabular}{|c|c|c|c|c|}
\hline \multirow[b]{2}{*}{ Strain } & \multicolumn{2}{|c|}{ S9 mix (-) } & \multicolumn{2}{|c|}{ S9 mix (+) } \\
\hline & $\begin{array}{l}\text { Chemical } \\
\text { substance }\end{array}$ & $\begin{array}{l}\text { Concentration } \\
(\mu \mathrm{g} / \mathrm{plate})\end{array}$ & $\begin{array}{l}\text { Chemical } \\
\text { substance }\end{array}$ & $\begin{array}{c}\text { Concentration } \\
(\mu \mathrm{g} / \text { plate })\end{array}$ \\
\hline TA98 & AF-2 & 0.1 & $2 \mathrm{AA}$ & 0.5 \\
\hline TA1537 & 9AA & 80.0 & $2 \mathrm{AA}$ & 2.0 \\
\hline TA100 & $\mathrm{AF}-2$ & 0.01 & $2 \mathrm{AA}$ & 1.0 \\
\hline TA1535 & SAZ & 0.5 & $2 \mathrm{AA}$ & 2.0 \\
\hline WP2uvrA & $\mathrm{AF}-2$ & 0.01 & $2 \mathrm{AA}$ & 10.0 \\
\hline
\end{tabular}


Safety assessment of hydrogenated resistant maltodextrin

trol and if the number of colonies showed a dose-dependent increase. In the case of results other than those mentioned above, samples were determined as negative.

\section{Animals}

Five-week-old Crj:CD(SD)IGS, SPF rats obtained from Charles River Laboratories Japan Inc. (Kanagawa, Japan) were housed individually in metallic cages in the animal experiment room where the temperature was set at $22 \pm 3{ }^{\circ} \mathrm{C}$, humidity at $50 \pm 20 \%$, ventilation frequency at $15 \pm 5$ times per hour, and lighting hours from 6:00 AM to 6:00 PM every day. All rats had free access to solid diet CRF-1 (Oriental Yeast Co., Ltd., Tokyo, Japan) and tap water sterilized using an autoclave and by ultraviolet radiation, respectively. Our study involved a 9-day preliminary feeding period before both rat studies.

\section{Acute oral toxicity study in rats}

We allocated 15 male and female rats each to 3 dose groups according to their body weight (BW) $(0,5$, and $10 \mathrm{~g} / \mathrm{kg} \mathrm{BW}$ groups; 10 rats/group) on the final day of prefeeding. The animals were fasted after 4:00 PM on the day before the study. We prepared 2 solutions of FS-2H $25 \% \mathrm{w} / \mathrm{v}$ and $50 \% \mathrm{w} / \mathrm{v}$ for injection. Each solution was orally administered by gavage using a stomach tube at a volume of $20 \mathrm{ml} / \mathrm{kg} \mathrm{BW}$. After administration, the general symptoms and the stool condition of each animal were observed over $6 \mathrm{hr}$, and the condition and the stool condition of each animal was observed every morning for 14 subsequent days. BW was measured before the treatment and 1,2, 4, 7, and 14 days after the treatment. At the end of the study (Day 14), all rats were killed by bleeding from the abdominal aorta under ether anesthesia and autopsy was performed.

\section{Ninety-day subchronic repeated oral toxicity study in rats}

We randomly allocated 30 male and female rats each to 3 dose groups (FS-2H 0, 2.5, and $5.0 \mathrm{~g} / \mathrm{kg} \mathrm{BW}$ groups; 10 males and 10 females/group). After prefeeding, one of the FS- $2 \mathrm{H}$ solutions, $25 \% \mathrm{w} / \mathrm{v}$ or $50 \% \mathrm{w} / \mathrm{v}$, was orally administered by gavage using a stomach tube at a volume of $10 \mathrm{ml} / \mathrm{kg} \mathrm{BW}$ once every morning for 90 days (13 weeks). Animals in the control group received only $10 \mathrm{ml} / \mathrm{kg} \mathrm{BW}$ of water administered orally in the same manner. During the treatment period, each animal was allowed free access to feed and water. Animals were fasted after 4:00 PM on the last day of the 90-day treatment period. On the next day, they were killed by bleeding from the abdominal aorta under ether anesthesia and autopsy was performed.
The mean daily feed consumption was calculated from the feed consumption in 2 consecutive days once during the prefeeding period and every week during the treatment period. BW was measured on the first day of administration and weekly during the treatment period.

During the last week of treatment, half of the males and females each were placed into metabolic cages and allowed free access to water supplied from a water bottle. Urine was collected for urinalysis, including the measurement of urine volume; specific gravity; color; $\mathrm{pH}$; the levels of sodium $(\mathrm{Na})$, potassium $(\mathrm{K})$, chlorine $(\mathrm{Cl})$, protein, glucose, ketone bodies, urobilinogen, and bilirubin; and the presence of occult blood, red blood cells (RBCs), white blood cells (WBCs), epithelial cells, cast, ammonium magnesium phosphate (AMP), and amorphous phosphate (AP). The remaining half of the males and females received examination of the anterior segment of eyes (cornea, conjunctiva, sclera, iris, etc.) and observation of the fundus and optic media.

Blood was sampled via the abdominal aorta under ether anesthesia for analysis of the following hematological and blood biochemical parameters: red blood cell count (RBC); white blood cell count (WBC); hematocrit $(\mathrm{Ht})$; mean corpuscular volume (MCV); mean corpuscular hemoglobin concentration $(\mathrm{MCHC})$; reticulocyte count (Ret); platelet count (PLT); prothrombin time (PT); activated partial thromboplastin time (APTT); albu$\mathrm{min} /$ globulin ratio $(\mathrm{A} / \mathrm{G})$; and the levels of hemoglobin $(\mathrm{Hb})$, mean corpuscular hemoglobin $(\mathrm{MCH})$, aspartate aminotransferase (AST), alanine aminotransferase (ALT), alkaline phosphatase (ALP), glucose (Glu), total cholesterol (T-Cho), triglyceride (TG), phospholipid $(\mathrm{PL})$, total protein (TP), albumin (Alb), blood urea nitrogen (BUN), creatinine (Cre), total bilirubin (T-Bil), Na, $\mathrm{K}, \mathrm{Cl}$, inorganic phosphorus $(\mathrm{P})$, calcium $(\mathrm{Ca})$, and protein fractions (albumin, $\alpha-1$ globulin, $\alpha-2$ globulin, $\beta$ globulin, and $\gamma$ globulin). Hematological test used the following methods. Prothrombin time and activated partial thromboplastin time were measured with an automated coagulation analyzer (KC-10A micro, Amelung, (Lemgo, Germany)). Reticulocytes were counted with the Brecher method. The other blood cells were counted with an automated blood cell counter (CC-180A, Sysmex Co. (Hyogo, Japan)). Blood biochemical test used the following methods. Protein fractions were measured with an electrophoresis device (Titan Gel Chamber, Helena Laboratories (Beaumont, TX, USA)) and a densitometer (Cliniscan 2, Helena Laboratories). The other blood biochemical parameters were measured with a biochemical autoanalyzer (Synchron CX7, Beckman Coulter, Inc. (Brea, CA, USA)). 
The major organs of all rats that underwent autopsy were weighed, and their weights were expressed as per $100 \mathrm{~g} \mathrm{BW}$. In the case of paired organs, the total weight of organs on both sides was used. The ileum, cecum, colon, liver, and kidney were fixed in $10 \%$ neutral buffered formalin for histological examination for the control group and the $5.0 \mathrm{~g} / \mathrm{kg} \mathrm{BW}$ group. The liver and cecum of rats in the $5.0 \mathrm{~g} / \mathrm{kg}$ BW group showed abnormalities in weight and macroscopic observation and thus histological examination of rats in the $2.5 \mathrm{~g} / \mathrm{kg} \mathrm{BW}$ group was also performed.

Animal studies were performed in accordance with "Ordinance on standard for conduct of non-clinical studies on safety of drugs (MHW Ordinance No. 21, March 26, 1997)."

\section{Acute no-effect level for diarrhea in humans}

The study in humans was performed in accordance with the Helsinki Declaration under approval of the Ethics Committee of the Kannondai Clinic, and the subjects included 50 healthy adults (25 men and 25 women) in their 20's to 50's who submitted informed consent statements after being completely informed about the study objectives and contents. The subjects were divided into 5 groups so that the mean BW was equal in each dose group (FS-2H 0.4, 0.5, 0.6, 0.8, and $1.0 \mathrm{~g} / \mathrm{kg} \mathrm{BW}$ groups; 10 subjects/group). The age (mean \pm S.D.) of the subjects was $35.0 \pm 11.1$ years (men, $37.5 \pm 11.6$ and women, $32.5 \pm 10.1$ ). BW (mean \pm S.D.) was $57.8 \pm 11.2 \mathrm{~kg}$ (men, $66.1 \pm 8.9 \mathrm{~kg}$ and women, $49.5 \pm 5.7 \mathrm{~kg}$ ). All subjects were instructed to take breakfast without fail. Each dose of FS-2H was dissolved in warm water to make a $200 \mathrm{ml}$ solution to be taken at 10:00 AM. The condition of the first stool after intake of the test solution was judged subjectively using the 5 points in an illustrated guide: dry solid, banana-shaped, pasty, muddy, and watery (Satouchi et al., 1993). Muddy stool and watery stool were determined as diarrhea. The dose level at which diarrhea did not occur in all subjects in each gender group was adopted as the acute no-effect level for diarrhea.

\section{Statistical analysis}

All data obtained in this study were expressed in mean \pm S.D. The data on BW, diet consumption, urinary parameters, hematological parameters, blood biochemical parameters, and organ weight were subjected to Bartlett's test of homogeneity of variance. If the variance was equal, one-way analysis of variance was performed. When this analysis revealed a significant difference, Dunnett's test was employed for intergroup comparison (between the treatment and control groups). If variance was not equal, non-parametric Dunnett's test was used for comparison with the control group. Significance level was set at 5\% (two-sided).

\section{RESULTS}

\section{Reverse mutation assay}

The number of reverse mutation colonies in the absence of the $\mathrm{S} 9$ mix in the positive control groups (AF2, SAZ, and 9AA treatment groups) increased by 3 -fold or more than those in the negative control group. The positive control group (2AA treatment group) showed a similar increase in the number of colonies in the presence of the S9 mix, which confirmed that the test bacterial strains reacted normally. The number of reverse mutation colonies of each bacterial strain in the $\mathrm{FS}-2 \mathrm{H}$ treatment groups at dose levels between 313 and 5,000 $\mu \mathrm{g} /$ plate was less than twice the number of colonies in the negative control group, regardless of the presence or absence of the $\mathrm{S} 9$ mix. These results indicate that FS-2H does not induce any reverse mutation under the current test conditions.

\section{Acute oral toxicity study in rats}

The BW did not differ significantly in any male and female rats among any of the FS-2H treatment groups and the control group until the end of the 14-day observation period.

No rats died during the observation period. Macroscopic examination did not reveal any abnormality in any of the rats. Thus, the $50 \%$ lethal dose $\left(\mathrm{LD}_{50}\right)$ of FS-2H in rats was estimated to be higher than $10 \mathrm{~g} / \mathrm{kg} \mathrm{BW}$.

Soft stool was found in 1 female rat in the control group at $5 \mathrm{hr}$ after administration. Mucous stool was found in 1 male and 1 female in the FS-2H $5 \mathrm{~g} / \mathrm{kg} \mathrm{BW}$ group around 2 to $4 \mathrm{hr}$ after administration. Watery stool was found in 1 female, and mucous and soft stool was found in 2 males and 1 female in the FS-2H $10 \mathrm{~g} / \mathrm{kg} \mathrm{BW}$ group around 3 to $6 \mathrm{hr}$ after administration.

During the observation period, soft stool and dirt remaining around the anus were observed in 3 males and 1 female in the control group, 4 males and 1 female in the FS-2H $5 \mathrm{~g} / \mathrm{kg} \mathrm{BW}$ group, and 4 males and 3 females in the FS-2H $10 \mathrm{~g} / \mathrm{kg} \mathrm{BW}$ group. No intergroup difference was observed in the incidence of these events; therefore, we concluded that FS-2H did not have any influence on these results.

The symptoms of watery, mucous, and soft stools observed in all rats were mild and transient and recovered to the normal condition without any treatment. 
Safety assessment of hydrogenated resistant maltodextrin

\section{Ninety-day subchronic repeated oral toxicity study in rats}

No rats died during the observation period. Soft stool was found in 1 male rat in the $2.5 \mathrm{~g} / \mathrm{BW}$ group on the ninth day of administration, which was only transient. No other FS-2H treatment-related changes were observed.

The changes of BW over time are shown in Fig.1. The $\mathrm{BW}$ of male rats in the FS-2H $2.5 \mathrm{~g} / \mathrm{kg} \mathrm{BW}$ group was significantly higher than that of the rats in the control group at the third week of administration, which was only
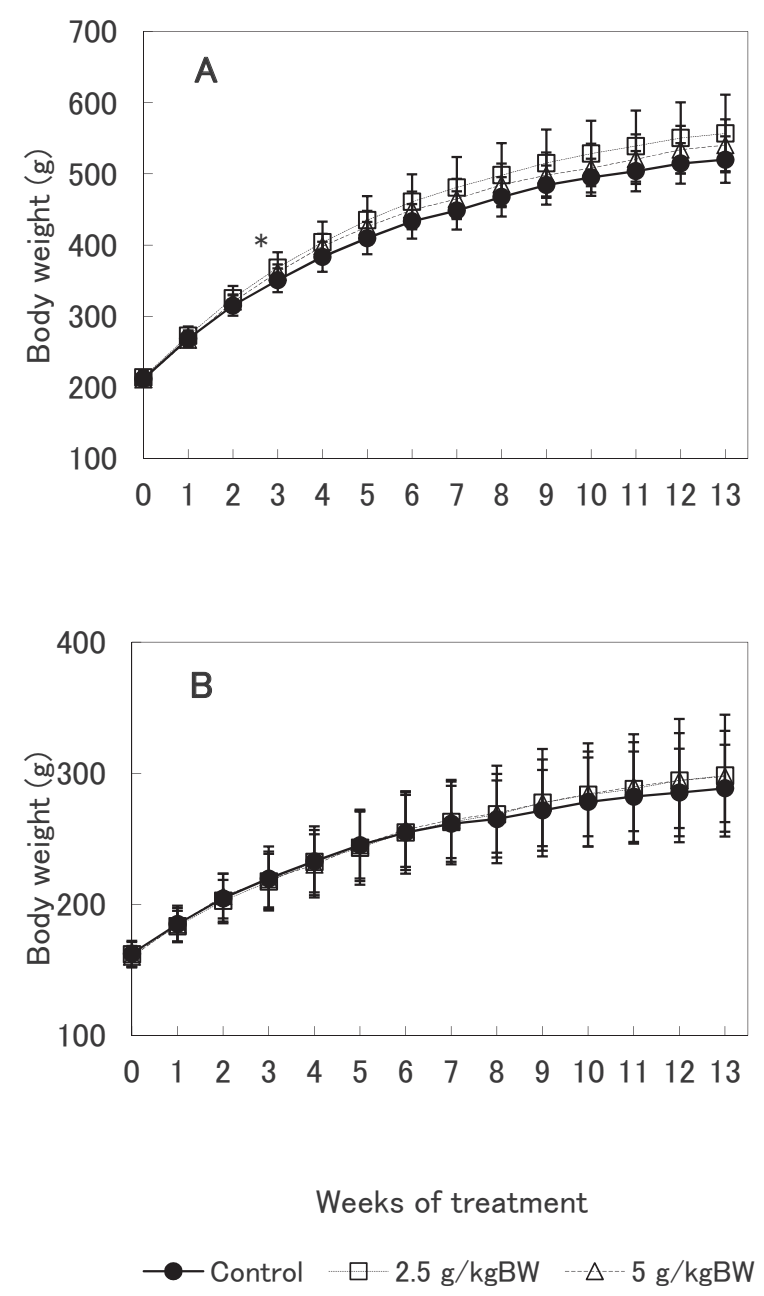

Fig. 1. Changes in the body weight of rats over the 90-day (13-week) experimental period. Time course of mean body weight (BW) after oral administration of hydrogenated resistant maltodextrin (FS-2H) every day to male(A) and female(B) rats at dose levels of $0 \mathrm{~g} /$ $\mathrm{kg} \mathrm{BW}(\bullet), 2.5 \mathrm{~g} / \mathrm{kg} \mathrm{BW}(\square)$, and $5.0 \mathrm{~g} / \mathrm{kg} \mathrm{BW}(\triangle)$. * Significantly different from the control by Dunnett's test at $p<0.05$. transient. At all the other time points of measurement during the administration period, no significant difference was observed in the BW between the control group and the FS-2H 2.5 or $5.0 \mathrm{~g} / \mathrm{kg}$ BW group for both genders. No significant differences were observed in feed consumption among all groups.

No abnormality was found in ophthalmological examination, including the external appearance, eyelid, conjunctiva, sclera, cornea, anterior chamber, iris, crystalline lens, vitreous body, or fundus in all animals.

The results of urinalysis are shown in Table 2. Compared to the male rats in control group, the male rats in the $5.0 \mathrm{~g} / \mathrm{kg} \mathrm{BW}$ group had significantly lower urinary volume and significantly higher values of specific gravity and the concentration of $\mathrm{Na}, \mathrm{K}$, and $\mathrm{Cl}$. However, no significant difference was observed in the total excreted amount of $\mathrm{Na}, \mathrm{K}$, and $\mathrm{Cl}$.

The results of hematological examination are shown in Table 3. The platelet count of male rats in the $5.0 \mathrm{~g} / \mathrm{kg}$ BW group was significantly higher than that of male rats in the control group.

The results of biochemical examination are shown in Table 4. No statistically significant difference was observed between any rats in the FS-2H treatment groups and the control group, although 2 males in the $5.0 \mathrm{~g} / \mathrm{kg}$ BW group showed a tendency of an increase in the levels of AST and ALT.

The data on the organ weight relative to BW are shown in Table 5. Compared to the males and females in the control group, males and females in the 2.5 and $5.0 \mathrm{~g} / \mathrm{kg} \mathrm{BW}$ groups showed a significant increase or a tendency of a dose-dependent increase in the weights of cecum alone, cecal contents alone, and cecum with cecal contents. No difference was observed in the other organs.

Histological examination showed hypertrophy of the cecal mucosal epithelium in 3 males and 4 females in the $5.0 \mathrm{~g} / \mathrm{kg} \mathrm{BW}$ group, but the extent of hypertrophy was mild in all the cases. A change similar to that observed in the $5.0 \mathrm{~g} / \mathrm{kg} \mathrm{BW}$ group was observed in 1 male and 2 females in the $2.5 \mathrm{~g} / \mathrm{kg}$ BW group. The liver of 2 males in the $5.0 \mathrm{~g} / \mathrm{kg} \mathrm{BW}$ group showed an increase in the levels of AST and ALT and had mild focal necrosis accompanied by inflammatory cell infiltration.

\section{Acute no-effect level for diarrhea in humans}

The result of the self-reported condition of the first stool after FS-2H intake is shown in Table 6. Diarrhea was not observed in any man or woman at any of the dose levels of $0.4,0.5,0.6$, and $0.8 \mathrm{~g} / \mathrm{kg} \mathrm{BW}$. At the dose level of $1.0 \mathrm{~g} / \mathrm{kg} \mathrm{BW}$, muddy stool was found in 2 men but in none of the women. Thus, the acute no-effect level for 
Y. Yoshikawa et al.

Table 2. Urinalysis data in rats administered FS-2H for 90 days.

\begin{tabular}{|c|c|c|c|c|c|c|c|}
\hline \multirow{2}{*}{\multicolumn{2}{|c|}{$\begin{array}{l}\text { Sex } \\
\text { Dose ( } g / k g \text { body weight) }\end{array}$}} & \multicolumn{3}{|c|}{ Male } & \multicolumn{3}{|c|}{ Female } \\
\hline & & Control & 2.5 & 5.0 & Control & 2.5 & 5.0 \\
\hline \multicolumn{2}{|c|}{ Number of animals } & 5 & 5 & 5 & 5 & 5 & 5 \\
\hline \multicolumn{2}{|c|}{ Volume (ml) } & $30.5 \pm 8.0$ & $22.8 \pm 3.1$ & $17.4 \pm 3.0^{* *}$ & $19.1 \pm 4.3$ & $13.7 \pm 5.9$ & $18.2 \pm 3.1$ \\
\hline \multicolumn{2}{|l|}{ Specific gravity } & $1.034 \pm 0.007$ & $1.042 \pm 0.003$ & $1.053 \pm 0.011^{* *}$ & $1.032 \pm 0.005$ & $1.045 \pm 0.020$ & $1.035 \pm 0.005$ \\
\hline \multicolumn{2}{|l|}{$\mathrm{Na}(\mathrm{mEq} / \mathrm{l})$} & $76.4 \pm 12.6$ & $93.4 \pm 4.8$ & $114.2 \pm 25.0^{* *}$ & $70.4 \pm 13.1$ & $93.6 \pm 26.7$ & $79.2 \pm 13.0$ \\
\hline \multicolumn{2}{|l|}{$\mathrm{K}(\mathrm{mEq} / \mathrm{l})$} & $166.9 \pm 35.6$ & $193.4 \pm 10.2$ & $254.6 \pm 53.1^{* *}$ & $154.6 \pm 36.2$ & $208.5 \pm 91.9$ & $161.6 \pm 30.9$ \\
\hline \multicolumn{2}{|l|}{$\mathrm{Cl}(\mathrm{mEq} / \mathrm{l})$} & $97.4 \pm 24.4$ & $119.4 \pm 7.1$ & $169.4 \pm 47.2^{* *}$ & $92.8 \pm 21.4$ & $134.2 \pm 56.2$ & $102.6 \pm 20.2$ \\
\hline \multicolumn{8}{|c|}{ Total excretion (mg/day) } \\
\hline \multicolumn{2}{|c|}{$\mathrm{Na}$} & $52.0 \pm 6.0$ & $49.0 \pm 7.4$ & $44.4 \pm 4.7$ & $30.0 \pm 3.9$ & $27.0 \pm 6.7$ & $33.0 \pm 7.0$ \\
\hline \multicolumn{2}{|l|}{$\mathrm{K}$} & $190.8 \pm 16.7$ & $172.2 \pm 22.5$ & $170.0 \pm 26.6$ & $111.8 \pm 14.5$ & $99.0 \pm 28.5$ & $114.0 \pm 24.4$ \\
\hline \multicolumn{2}{|l|}{$\mathrm{Cl}$} & $100.8 \pm 14.5$ & $96.6 \pm 13.7$ & $101.8 \pm 19.7$ & $60.8 \pm 8.2$ & $57.6 \pm 13.7$ & $66.2 \pm 18.0$ \\
\hline \multirow[t]{3}{*}{ Color } & $\mathrm{Y}$ & 0 & 0 & 1 & 0 & 1 & 1 \\
\hline & TY & 4 & 5 & 3 & 5 & 4 & 4 \\
\hline & $\mathrm{AU}$ & 1 & 0 & 1 & 0 & 0 & 0 \\
\hline \multirow[t]{3}{*}{$\mathrm{pH}$} & 7.5 & 0 & 0 & 0 & 0 & 0 & 1 \\
\hline & 8.0 & 0 & 0 & 0 & 1 & 3 & 0 \\
\hline & 8.5 & 5 & 5 & 5 & 4 & 2 & 4 \\
\hline \multirow[t]{2}{*}{ Protein } & - & 1 & 4 & 1 & 5 & 4 & 5 \\
\hline & \pm & 4 & 1 & 4 & 0 & 1 & 0 \\
\hline Glucose & - & 5 & 5 & 5 & 5 & 5 & 5 \\
\hline \multirow[t]{2}{*}{ Ketone bodies } & - & 3 & 3 & 2 & 5 & 5 & 5 \\
\hline & \pm & 2 & 2 & 3 & 0 & 0 & 0 \\
\hline Urobilinogen & \pm & 5 & 5 & 5 & 5 & 5 & 5 \\
\hline Bilirubin & - & 5 & 5 & 5 & 5 & 5 & 5 \\
\hline Occult blood & - & 5 & 5 & 5 & 5 & 5 & 5 \\
\hline
\end{tabular}

\begin{tabular}{|c|c|c|c|c|c|c|c|}
\hline \multicolumn{8}{|c|}{ Urinary sediments } \\
\hline RBCs & - & 5 & 5 & 5 & 5 & 5 & 5 \\
\hline \multirow[t]{2}{*}{ WBCs } & - & 2 & 2 & 2 & 3 & 3 & 3 \\
\hline & \pm & 3 & 3 & 3 & 2 & 2 & 2 \\
\hline \multirow[t]{2}{*}{ Epithelial cells } & - & 0 & 0 & 0 & 0 & 1 & 1 \\
\hline & \pm & 5 & 5 & 5 & 5 & 4 & 4 \\
\hline Cast & - & 5 & 5 & 5 & 5 & 5 & 5 \\
\hline \multirow[t]{2}{*}{ AMP } & - & 5 & 4 & 4 & 4 & 4 & 4 \\
\hline & + & 0 & 1 & 1 & 1 & 1 & 1 \\
\hline \multirow[t]{2}{*}{ AP } & - & 5 & 5 & 5 & 5 & 4 & 4 \\
\hline & + & 0 & 0 & 0 & 0 & 1 & 1 \\
\hline
\end{tabular}

Values are expressed as the mean \pm S.D. ${ }^{* *}$ Significantly different from the control by Dunnett's test at $p<0.01$. Numerals represent the number of animals with the findings. Color: Y, Yellow; T, Thin; AU, Achromatic urine. Protein: -, Negative; \pm , Trace. Glucose: -, Negative. Ketone bodies: -, Negative;, $\pm 5 \mathrm{mg} / \mathrm{dl}$. Urobilinogen:, $\pm 0.1-1 \mathrm{Ehr} / \mathrm{dl}$. Bilirubin: -, Negative. Occult blood: -, Negative. RBCs:,- 0 cells/field. WBCs:,$- 0 ; \pm,<6$ cells/field. Epithelial cells:,$- 0 ; \pm,<6$ cells/field. Cast: -, Negative. AMP: - , Negative; +, Positive. AP: -, Negative; +, Positive. 
Safety assessment of hydrogenated resistant maltodextrin

Table 3. Hematology data in rats administered FS-2H for 90 days.

\begin{tabular}{|c|c|c|c|c|}
\hline \multicolumn{2}{|c|}{ Dose (g/kg body weight) } & Control & 2.5 & 5.0 \\
\hline \multicolumn{2}{|c|}{ Number of animals } & 10 & 10 & 10 \\
\hline \multirow[t]{11}{*}{ Male } & $\operatorname{RBC}\left(10^{4} / \mathrm{mm}^{3}\right)$ & $940 \pm 32$ & $951 \pm 17$ & $945 \pm 24$ \\
\hline & WBC $\left(10^{2} / \mathrm{mm}^{3}\right)$ & $85.7 \pm 34.7$ & $102.0 \pm 32.5$ & $105.7 \pm 32.0$ \\
\hline & $\mathrm{Ht}(\%)$ & $46.3 \pm 1.6$ & $46.2 \pm 1.4$ & $45.8 \pm 1.3$ \\
\hline & $\mathrm{Hb}(\mathrm{g} / \mathrm{dl})$ & $16.3 \pm 0.5$ & $16.2 \pm 0.4$ & $16.3 \pm 0.5$ \\
\hline & $\mathrm{MCH}(\mathrm{pg})$ & $17.3 \pm 0.5$ & $17.0 \pm 0.5$ & $17.3 \pm 0.7$ \\
\hline & $\operatorname{MCV}\left(\mu^{3}\right)$ & $49.0 \pm 1.9$ & $48.5 \pm 1.3$ & $48.4 \pm 1.6$ \\
\hline & $\mathrm{MCHC}(\%)$ & $35.2 \pm 0.4$ & $35.1 \pm 0.6$ & $35.6 \pm 0.4$ \\
\hline & Ret (\%) & $19.9 \pm 4.4$ & $21.1 \pm 4.4$ & $20.2 \pm 3.2$ \\
\hline & $\operatorname{PLT}\left(10^{4} / \mathrm{mm}^{3}\right)$ & $89.4 \pm 10.0$ & $96.9 \pm 9.9$ & $103.8 \pm 12.7^{*}$ \\
\hline & $\mathrm{PT}(\mathrm{s})$ & $12.7 \pm 1.3$ & $12.8 \pm 0.9$ & $12.2 \pm 0.4$ \\
\hline & APTT (s) & $33.3 \pm 4.3$ & $34.4 \pm 6.2$ & $31.4 \pm 4.3$ \\
\hline \multirow[t]{11}{*}{ Female } & $\mathrm{RBC}\left(10^{4} / \mathrm{mm}^{3}\right)$ & $852 \pm 30$ & $842 \pm 31$ & $846 \pm 28$ \\
\hline & $\mathrm{WBC}\left(10^{2} / \mathrm{mm}^{3}\right)$ & $52.1 \pm 16.5$ & $65.3 \pm 20.6$ & $62.8 \pm 18.0$ \\
\hline & $\mathrm{Ht}(\%)$ & $43.8 \pm 1.1$ & $43.4 \pm 1.6$ & $43.4 \pm 1.4$ \\
\hline & $\mathrm{Hb}(\mathrm{g} / \mathrm{dl})$ & $15.9 \pm 0.4$ & $15.6 \pm 0.5$ & $15.7 \pm 0.5$ \\
\hline & $\mathrm{MCH}(\mathrm{pg})$ & $18.6 \pm 0.4$ & $18.5 \pm 0.4$ & $18.6 \pm 0.6$ \\
\hline & $\operatorname{MCV}\left(\mu^{3}\right)$ & $51.4 \pm 1.2$ & $51.5 \pm 1.3$ & $51.4 \pm 1.7$ \\
\hline & MCHC (\%) & $36.2 \pm 0.5$ & $35.8 \pm 0.4$ & $36.2 \pm 0.4$ \\
\hline & Ret (\%o) & $18.7 \pm 3.6$ & $19.6 \pm 4.6$ & $17.6 \pm 4.8$ \\
\hline & $\operatorname{PLT}\left(10^{4} / \mathrm{mm}^{3}\right)$ & $94.1 \pm 10.7$ & $93.4 \pm 9.0$ & $92.6 \pm 8.4$ \\
\hline & PT (s) & $11.4 \pm 0.6$ & $11.6 \pm 0.7$ & $11.6 \pm 0.7$ \\
\hline & APTT (s) & $25.3 \pm 3.4$ & $23.7 \pm 2.8$ & $23.4 \pm 1.9$ \\
\hline
\end{tabular}

Values are expressed as the mean \pm S.D. *, Significantly different from the control by Dunnett's test at $p<0.05$.

diarrhea was estimated to be $0.8 \mathrm{~g} / \mathrm{kg} \mathrm{BW}$ for men and more than $1.0 \mathrm{~g} / \mathrm{kg} \mathrm{BW}$ for women.

The subjective gastrointestinal symptoms were as follows: 1 subject in the $0.4 \mathrm{~g} / \mathrm{kg}$ BW group experienced bloating of the abdomen, and 1 subject each in the 0.8 and $1.0 \mathrm{~g} / \mathrm{kg} \mathrm{BW}$ groups experienced abdominal pain, tenesmus, and bloating of the abdomen. Gargling sound was reported by 1 or 2 subjects each in the $0.4,0.6$, and $1.0 \mathrm{~g} / \mathrm{kg}$ BW male groups and 1 or 2 subjects each in $0.5,0.8$, and $1.0 \mathrm{~g} / \mathrm{kg} \mathrm{BW}$ female groups. Flatus was reported by 1 subject each in the 0.5 to $1.0 \mathrm{~g} / \mathrm{kg} \mathrm{BW}$ male group and 1 subject in the $0.5 \mathrm{~g} / \mathrm{kg} \mathrm{BW}$ female group. The incidences of gargling sound or flatus were not dose-dependent. All of these symptoms were mild and transient and recovered to normal without any treatment. No other clinical symptoms that led to discontinuation of the experiment were observed in all subjects.

\section{DISCUSSION}

We performed the reverse mutation assay as a part of the series of safety assessments of FS-2H; the results of the assay indicated that FS-2H was not mutagenic.

Next, we performed an acute oral toxicity study in rats. FS-2H $50 \% \mathrm{w} / \mathrm{v}$ (the highest soluble concentration of FS$2 \mathrm{H}$ ) was set as the high dose. A dose of $20 \mathrm{ml} / \mathrm{kg} \mathrm{BW}$ was estimated to be the highest possible volume for a single oral dose by gavage. Thus, the high dose level was $10 \mathrm{~g} / \mathrm{kg} \mathrm{BW}$ and the low dose level was set at the half of it. Our results indicated that no deaths occurred even at the high dose level, $10 \mathrm{~g} / \mathrm{kg} \mathrm{BW}$, and the change in $\mathrm{BW}$ in this group during the observation period was similar to that in the control group. Pathological examination revealed no abnormality in any group.

Within $6 \mathrm{hr}$ after administration, soft stool was observed 
Y. Yoshikawa et al.

Table 4. Blood biochemistry data in rats administered FS-2H for 90 days.

\begin{tabular}{|c|c|c|c|c|}
\hline Dose $(g /$ & weight) & Control & 2.5 & 5.0 \\
\hline Number & & 10 & 10 & 10 \\
\hline Male & AST (IU/1) & $70.7 \pm 10.3$ & $71.0 \pm 16.1$ & $152.6 \pm 218.3$ \\
\hline & ALT (IU/l) & $31.6 \pm 5.1$ & $32.6 \pm 13.2$ & $101.2 \pm 183.3$ \\
\hline & ALP (IU/1) & $106.0 \pm 28.3$ & $97.9 \pm 24.0$ & $97.4 \pm 18.3$ \\
\hline & Glu (mg/dl) & $158.7 \pm 30.2$ & $146.7 \pm 12.7$ & $153.1 \pm 15.2$ \\
\hline & T-Cho (mg/dl) & $31.0 \pm 5.9$ & $31.3 \pm 7.8$ & $33.6 \pm 6.1$ \\
\hline & $\mathrm{TG}(\mathrm{mg} / \mathrm{dl})$ & $33.3 \pm 17.3$ & $40.4 \pm 16.1$ & $35.2 \pm 15.6$ \\
\hline & PL (mg/dl) & $95.1 \pm 12.2$ & $94.2 \pm 13.9$ & $96.9 \pm 12.5$ \\
\hline & $\mathrm{TP}(\mathrm{g} / \mathrm{dl})$ & $6.5 \pm 0.2$ & $6.6 \pm 0.4$ & $6.4 \pm 0.2$ \\
\hline & Alb (g/dl) & $2.3 \pm 0.1$ & $2.4 \pm 0.1$ & $2.3 \pm 0.1$ \\
\hline & $\mathrm{A} / \mathrm{G}$ & $0.56 \pm 0.03$ & $0.56 \pm 0.03$ & $0.57 \pm 0.03$ \\
\hline & BUN (mg/dl) & $18.2 \pm 2.3$ & $17.7 \pm 1.3$ & $17.3 \pm 3.0$ \\
\hline & Cre (mg/dl) & $0.61 \pm 0.09$ & $0.60 \pm 0.09$ & $0.61 \pm 0.08$ \\
\hline & T-Bil (mg/dl) & $0.35 \pm 0.09$ & $0.36 \pm 0.08$ & $0.40 \pm 0.09$ \\
\hline & $\mathrm{Na}(\mathrm{mEq} / \mathrm{l})$ & $143.7 \pm 1.4$ & $143.4 \pm 1.3$ & $142.6 \pm 1.2$ \\
\hline & $\mathrm{K}(\mathrm{mEq} / \mathrm{l})$ & $4.7 \pm 0.4$ & $5.0 \pm 0.3$ & $4.9 \pm 0.5$ \\
\hline & $\mathrm{Cl}(\mathrm{mEq} / \mathrm{l})$ & $112.5 \pm 3.4$ & $111.3 \pm 1.6$ & $110.3 \pm 1.6$ \\
\hline & $\mathrm{P}(\mathrm{mg} / \mathrm{dl})$ & $6.4 \pm 0.7$ & $6.3 \pm 0.8$ & $6.8 \pm 0.8$ \\
\hline & $\mathrm{Ca}(\mathrm{mg} / \mathrm{dl})$ & $9.5 \pm 0.3$ & $9.6 \pm 0.2$ & $9.5 \pm 0.3$ \\
\hline & Protein fraction & & & \\
\hline & Albumin & $46.5 \pm 2.0$ & $46.5 \pm 2.2$ & $47.6 \pm 1.6$ \\
\hline & $\alpha-1$ Globulin & $22.7 \pm 1.5$ & $24.1 \pm 2.2$ & $22.3 \pm 1.7$ \\
\hline & $\alpha-2$ Globulin & $8.0 \pm 0.6$ & $7.5 \pm 0.9$ & $8.1 \pm 0.7$ \\
\hline & $\beta$ Globulin & $16.6 \pm 1.1$ & $16.2 \pm 0.8$ & $16.0 \pm 1.3$ \\
\hline & $\gamma$ Globulin & $6.2 \pm 1.1$ & $5.6 \pm 0.9$ & $6.1 \pm 1.4$ \\
\hline Female & AST (IU/l) & $88.4 \pm 63.7$ & $65.6 \pm 16.3$ & $68.7 \pm 17.1$ \\
\hline & ALT (IU/l) & $43.7 \pm 41.5$ & $26.5 \pm 7.3$ & $29.8 \pm 13.3$ \\
\hline & ALP (IU/1) & $44.6 \pm 14.2$ & $44.8 \pm 13.9$ & $45.6 \pm 17.0$ \\
\hline & Glu (mg/dl) & $118.0 \pm 20.0$ & $127.7 \pm 21.1$ & $138.8 \pm 21.1$ \\
\hline & T-Cho (mg/dl) & $37.2 \pm 5.6$ & $34.2 \pm 9.6$ & $36.1 \pm 6.5$ \\
\hline & $\mathrm{TG}(\mathrm{mg} / \mathrm{dl})$ & $20.7 \pm 15.1$ & $21.4 \pm 10.9$ & $23.5 \pm 11.0$ \\
\hline & PL (mg/dl) & $127.2 \pm 13.9$ & $119.1 \pm 26.5$ & $124.3 \pm 17.7$ \\
\hline & $\mathrm{TP}(\mathrm{g} / \mathrm{dl})$ & $6.6 \pm 0.3$ & $6.7 \pm 0.4$ & $6.8 \pm 0.6$ \\
\hline & $\mathrm{Alb}(\mathrm{g} / \mathrm{dl})$ & $2.7 \pm 0.2$ & $2.6 \pm 0.2$ & $2.7 \pm 0.3$ \\
\hline & $\mathrm{A} / \mathrm{G}$ & $0.68 \pm 0.03$ & $0.66 \pm 0.03$ & $0.67 \pm 0.04$ \\
\hline & BUN (mg/dl) & $19.2 \pm 2.5$ & $19.3 \pm 1.8$ & $17.4 \pm 2.2$ \\
\hline & Cre (mg/dl) & $0.64 \pm 0.06$ & $0.64 \pm 0.06$ & $0.64 \pm 0.07$ \\
\hline & T-Bil (mg/dl) & $0.34 \pm 0.14$ & $0.42 \pm 0.12$ & $0.41 \pm 0.16$ \\
\hline & $\mathrm{Na}(\mathrm{mEq} / \mathrm{l})$ & $143.8 \pm 1.3$ & $143.0 \pm 0.8$ & $143.1 \pm 1.0$ \\
\hline & $\mathrm{K}(\mathrm{mEq} / \mathrm{l})$ & $4.2 \pm 0.2$ & $4.0 \pm 0.3$ & $4.2 \pm 0.3$ \\
\hline & $\mathrm{Cl}(\mathrm{mEq} / \mathrm{l})$ & $114.1 \pm 1.4$ & $113.4 \pm 1.7$ & $113.6 \pm 1.9$ \\
\hline & $\mathrm{P}(\mathrm{mg} / \mathrm{dl})$ & $5.1 \pm 1.4$ & $5.0 \pm 0.9$ & $4.8 \pm 1.0$ \\
\hline & $\mathrm{Ca}(\mathrm{mg} / \mathrm{dl})$ & $9.7 \pm 0.1$ & $9.9 \pm 0.2$ & $10.0 \pm 0.4$ \\
\hline & Protein fraction & & & \\
\hline & Albumin & $54.9 \pm 3.6$ & $55.1 \pm 3.7$ & $55.8 \pm 2.6$ \\
\hline & $\alpha-1$ Globulin & $16.9 \pm 1.9$ & $17.2 \pm 1.8$ & $16.7 \pm 1.8$ \\
\hline & $\alpha-2$ Globulin & $7.0 \pm 1.0$ & $6.8 \pm 1.0$ & $6.6 \pm 1.3$ \\
\hline & $\beta$ Globulin & $14.3 \pm 1.6$ & $13.9 \pm 1.9$ & $13.7 \pm 1.8$ \\
\hline & $\gamma$ Globulin & $6.9 \pm 1.5$ & $7.0 \pm 2.0$ & $7.2 \pm 1.5$ \\
\hline
\end{tabular}

Values are expressed as the mean \pm S.D. 
Safety assessment of hydrogenated resistant maltodextrin

Table 5. Relative organ weight (/100 g body weight) data in rats administered FS-2H for 90 days.

\begin{tabular}{|c|c|c|c|c|}
\hline \multicolumn{2}{|c|}{ Dose (g/kg body weight) } & Control & 2.5 & 5.0 \\
\hline \multicolumn{2}{|c|}{ Number of animals } & 10 & 10 & 10 \\
\hline \multirow[t]{23}{*}{ Male } & Body weight (g) & $492 \pm 29$ & $527 \pm 51$ & $511 \pm 32$ \\
\hline & Brain $(g)$ & $0.43 \pm 0.02$ & $0.41 \pm 0.03$ & $0.41 \pm 0.02$ \\
\hline & Pituitary gland (mg) & $2.7 \pm 0.3$ & $2.6 \pm 0.2$ & $2.8 \pm 0.2$ \\
\hline & Thyroid glands (mg) & $5.1 \pm 0.6$ & $5.0 \pm 0.7$ & $5.2 \pm 0.6$ \\
\hline & Submaxillary glands (mg) & $152 \pm 28$ & $138 \pm 15$ & $140 \pm 13$ \\
\hline & Thymus (mg) & $48.1 \pm 12.4$ & $56.2 \pm 16.8$ & $59.6 \pm 10.8$ \\
\hline & Heart (mg) & $267 \pm 15$ & $260 \pm 18$ & $266 \pm 17$ \\
\hline & Lung $(g)$ & $0.30 \pm 0.02$ & $0.28 \pm 0.02$ & $0.30 \pm 0.02$ \\
\hline & Liver $(g)$ & $2.52 \pm 0.20$ & $2.62 \pm 0.20$ & $2.52 \pm 0.19$ \\
\hline & Spleen (mg) & $151 \pm 25$ & $146 \pm 9$ & $143 \pm 16$ \\
\hline & Kidneys (g) & $0.59 \pm 0.04$ & $0.58 \pm 0.04$ & $0.59 \pm 0.04$ \\
\hline & Adrenal glands (mg) & $10.4 \pm 1.3$ & $9.8 \pm 1.2$ & $9.5 \pm 0.9$ \\
\hline & Cecum with cecal contents ( $\mathrm{g}$ ) & $0.72 \pm 0.14$ & $1.00 \pm 0.22$ & $1.70 \pm 0.46^{* *}$ \\
\hline & Cecum $(g)$ & $0.25 \pm 0.03$ & $0.30 \pm 0.02^{*}$ & $0.40 \pm 0.05^{* *}$ \\
\hline & Cecal contents $(\mathrm{g})$ & $0.47 \pm 0.13$ & $0.69 \pm 0.21$ & $1.29 \pm 0.42^{* *}$ \\
\hline & Stomach $(g)$ & $0.37 \pm 0.03$ & $0.36 \pm 0.02$ & $0.34 \pm 0.02$ \\
\hline & Duodenum (g) & $0.13 \pm 0.02$ & $0.12 \pm 0.02$ & $0.12 \pm 0.02$ \\
\hline & Jejunum/ileum (g) & $1.39 \pm 0.15$ & $1.47 \pm 0.14$ & $1.47 \pm 0.10$ \\
\hline & Colon/rectum (g) & $0.42 \pm 0.05$ & $0.45 \pm 0.05$ & $0.44 \pm 0.06$ \\
\hline & Testes $(\mathrm{g})$ & $0.66 \pm 0.04$ & $0.63 \pm 0.10$ & $0.66 \pm 0.05$ \\
\hline & Epididymides (mg) & $266 \pm 22$ & $250 \pm 38$ & $263 \pm 23$ \\
\hline & Seminal vesicles (mg) & $357 \pm 85$ & $323 \pm 44$ & $345 \pm 36$ \\
\hline & Prostate $(\mathrm{mg})$ & $182 \pm 33$ & $197 \pm 32$ & $188 \pm 48$ \\
\hline \multirow[t]{21}{*}{ Female } & Body weight (g) & $269 \pm 33$ & $279 \pm 42$ & $278 \pm 34$ \\
\hline & Brain $(g)$ & $0.72 \pm 0.08$ & $0.70 \pm 0.08$ & $0.70 \pm 0.06$ \\
\hline & Pituitary gland (mg) & $6.6 \pm 0.7$ & $7.0 \pm 0.8$ & $6.8 \pm 0.8$ \\
\hline & Thyroid glands (mg) & $8.0 \pm 0.7$ & $7.4 \pm 1.2$ & $7.5 \pm 0.7$ \\
\hline & Submaxillary glands (mg) & $167 \pm 16$ & $169 \pm 17$ & $165 \pm 14$ \\
\hline & Thymus (mg) & $95.1 \pm 39.1$ & $91.5 \pm 21.6$ & $89.2 \pm 26.9$ \\
\hline & Heart (mg) & $315 \pm 23$ & $302 \pm 29$ & $302 \pm 10$ \\
\hline & Lung $(g)$ & $0.40 \pm 0.03$ & $0.40 \pm 0.03$ & $0.42 \pm 0.03$ \\
\hline & Liver $(g)$ & $2.46 \pm 0.16$ & $2.56 \pm 0.23$ & $2.58 \pm 0.16$ \\
\hline & Spleen (mg) & $164 \pm 21$ & $176 \pm 35$ & $177 \pm 18$ \\
\hline & Kidneys (g) & $0.63 \pm 0.04$ & $0.64 \pm 0.06$ & $0.64 \pm 0.03$ \\
\hline & Adrenal glands (mg) & $22.9 \pm 2.3$ & $24.3 \pm 3.2$ & $23.0 \pm 3.0$ \\
\hline & Cecum with cecal contents (g) & $0.93 \pm 0.26$ & $1.40 \pm 0.25^{* *}$ & $1.68 \pm 0.34^{* *}$ \\
\hline & Cecum $(g)$ & $0.35 \pm 0.03$ & $0.44 \pm 0.03^{* *}$ & $0.52 \pm 0.04^{* *}$ \\
\hline & Cecal contents (g) & $0.58 \pm 0.26$ & $0.96 \pm 0.24^{* *}$ & $1.16 \pm 0.32^{* *}$ \\
\hline & Stomach $(g)$ & $0.48 \pm 0.04$ & $0.48 \pm 0.05$ & $0.50 \pm 0.03$ \\
\hline & Duodenum $(\mathrm{g})$ & $0.17 \pm 0.02$ & $0.19 \pm 0.03$ & $0.19 \pm 0.02$ \\
\hline & Jejunum/ileum (g) & $1.96 \pm 0.30$ & $1.96 \pm 0.12$ & $2.04 \pm 0.20$ \\
\hline & Colon/rectum (g) & $0.56 \pm 0.04$ & $0.64 \pm 0.08^{*}$ & $0.60 \pm 0.08$ \\
\hline & Ovaries (mg) & $38.5 \pm 8.4$ & $42.8 \pm 6.3$ & $41.0 \pm 5.5$ \\
\hline & Uterus (mg) & $216 \pm 56$ & $224 \pm 73$ & $222 \pm 53$ \\
\hline
\end{tabular}

Values are expressed as the mean \pm S.D. ${ }^{*}{ }^{* *}$ Significantly different from the control by Dunnett's test at $p<0.05$ and $p<0.01$, respectively. 
Y. Yoshikawa et al.

Table 6. Effect of FS-2H administration on the first stool condition in human subjects.

\begin{tabular}{|c|c|c|c|c|c|c|}
\hline \multicolumn{2}{|c|}{ Dose (g/kg body weight) } & \multirow{2}{*}{$\begin{array}{c}0.4 \\
10\end{array}$} & \multirow{2}{*}{$\begin{array}{l}0.5 \\
10\end{array}$} & \multirow{2}{*}{$\begin{array}{c}0.6 \\
10\end{array}$} & \multirow{2}{*}{$\begin{array}{c}0.8 \\
10\end{array}$} & \multirow{2}{*}{$\begin{array}{l}1.0 \\
10\end{array}$} \\
\hline Number of subje & & & & & & \\
\hline \multirow[t]{3}{*}{ Dry solid } & Male & 0 & 1 & 0 & 0 & 0 \\
\hline & Female & 0 & 2 & 0 & 0 & 0 \\
\hline & Total & 0 & 3 & 0 & 0 & 0 \\
\hline \multirow[t]{3}{*}{ Banana-shaped } & Male & 1 & 4 & 2 & 4 & 1 \\
\hline & Female & 4 & 3 & 2 & 4 & 3 \\
\hline & Total & 5 & 7 & 4 & 8 & 4 \\
\hline \multirow[t]{3}{*}{ Pasty } & Male & 4 & 0 & 3 & 1 & 2 \\
\hline & Female & 1 & 0 & 3 & 1 & 2 \\
\hline & Total & 5 & 0 & 6 & 2 & 4 \\
\hline \multirow[t]{3}{*}{ Muddy } & Male & 0 & 0 & 0 & 0 & 2 \\
\hline & Female & 0 & 0 & 0 & 0 & 0 \\
\hline & Total & 0 & 0 & 0 & 0 & 2 \\
\hline \multirow[t]{3}{*}{ Watery } & Male & 0 & 0 & 0 & 0 & 0 \\
\hline & Female & 0 & 0 & 0 & 0 & 0 \\
\hline & Total & 0 & 0 & 0 & 0 & 0 \\
\hline
\end{tabular}

Characteristics of the first stool after intake of FS-2H at a dose level of $0.4,0.5,0.6,0.8$, or $1.0 \mathrm{~g} / \mathrm{kg}$ body weight.

in the control group, and mucous or watery stools were observed in the FS-2H treatment group. These symptoms were transient and were associated with the osmotic pressure caused by intake of the high concentrations of FS-2H (25\% to $50 \%)$; results similar to ours have been reported previously on FS-2 (Wakabayashi et al., 1992). The BW in the FS-2H group on the day after administration did not differ from that in the control group, which led to the judgment that administration of FS-2H had a minimal influence. Consequently, these symptoms were considered to have no toxicological implication, and the NOAEL of FS-2H is estimated to be $10 \mathrm{~g} / \mathrm{kg} \mathrm{BW}$ or more on the acute oral toxicity study.

For evaluating the subchronic safety of continuous intake of FS-2H, we performed a 90-day subchronic repeated oral toxicity study in rats. Our results revealed dose-dependent increases in the weights of cecum alone, cecal contents alone, and cecum with cecal contents as well as hypertrophy of the cecal mucosal epithelium. Several studies in rats have reported that the indigestible polysaccharides are not digested or absorbed in the upper digestive tract and thus these polysaccharides are partially fermented by enterobacteria in the cecum, producing short-chain fatty acids (SCFA) etc., which decrease the $\mathrm{pH}$ of the cecum and promote hypertrophy of the cecal and colonic mucosa and cell proliferation (Lupton et al., 1988; Oku et al., 1979, 1982; Sakata, 1987; Yoshioka et al., 1994). FS-2, which is the original constituent of FS-2H, is fermented by Bifidobacterium and Bacteroides among enterobacteria (Ohkuma et al., 1990), and FS-2 treatment results in an increase in the SCFA lev$\mathrm{el}$ in the cecal contents, a decrease in the $\mathrm{pH}$ of the cecal contents, and an increase in the weights of cecum with cecal contents and the cecum itself (Wakabayashi et al., 1991, 1992). Similarly, FS-2H is fermented by Bifidobacterium and Bacteroides (Tagami et al., 2012). Consequently, the increase in the weights of cecum and cecal contents and hypertrophy of the cecal mucosal epithelium observed in our study are considered to be common physiological responses after intake of indigestible polysaccharides, i.e., brought by FS-2H partially fermented by intestinal microflora after reaching the cecum.

Other changes observed were focal necrosis in the liver and increased levels of AST and ALT, possibly caused by 
Safety assessment of hydrogenated resistant maltodextrin

the necrosis, in 2 males of the $5.0 \mathrm{~g} / \mathrm{kg} \mathrm{BW}$ group. Focal necrosis of the liver is a spontaneous change observed at a relatively higher incidence $(6.4 \%)$ in the male Crj:CD(SD) IGS rats (Noto et al., 1999). Excluding these 2 rats, the AST and ALT levels of all males (AST, $65.8 \pm$ 61.1 IU/1 and ALT, $29.5 \pm 46.4 \mathrm{IU} / 1)$ and females in the $5.0 \mathrm{~g} / \mathrm{kg} \mathrm{BW}$ group were similar to those in the control group. In addition, histological examination revealed no abnormality in the liver. Therefore, the focal necrosis of the liver is not assumed to be associated with FS-2H.

Urinalysis indicated that male rats in the $5.0 \mathrm{~g} / \mathrm{kg} \mathrm{BW}$ group showed significant decrease in urinary volume and significant increases in specific gravity and the concentrations of $\mathrm{Na}, \mathrm{K}$, and $\mathrm{Cl}$. However, no intergroup differences were observed in the total excreted amounts of $\mathrm{Na}, \mathrm{K}$, and $\mathrm{Cl}$. In addition, the levels of BUN and Cre and histological examination indicated no abnormality in the kidney, which suggested that the renal function was not disturbed.

Hematological examination showed that male rats in the $5.0 \mathrm{~g} / \mathrm{kg} \mathrm{BW}$ group had significantly higher platelet count than male rats in the control group. However, the platelet count remained within the normal range for animals at the same facility, and the increase in the platelet count was not remarkable. No change was observed in total RBC or blood coagulation system (PT, APTT), which suggested no possibility of development of myeloproliferative disease and anemia. Thus, the changes observed were not considered to have any toxicological implication. No other notable changes or abnormalities were observed during the experimental period. The results of 90-day subchronic repeated oral toxicity study in rats revealed that FS-2H is not toxic, and the NOAEL of FS$2 \mathrm{H}$ is estimated to be $5.0 \mathrm{~g} / \mathrm{kg} \mathrm{BW} /$ day or more.

Generally, diarrhea is a concern after excessive intake of indigestible carbohydrates at high doses. Therefore, a single-dose study of FS-2H in healthy adult humans was performed, and the results indicated that acute no-effect level of FS-2H for diarrhea was $0.8 \mathrm{~g} / \mathrm{kg} \mathrm{BW}$ for men and higher than $1.0 \mathrm{~g} / \mathrm{kg} \mathrm{BW}$ for women. The acute no-effect level for diarrhea of other indigestible carbohydrates is as follows: fructooligosaccharide, $0.30 \mathrm{~g} / \mathrm{kg} \mathrm{BW}$ for men and $0.40 \mathrm{~g} / \mathrm{kg} \mathrm{BW}$ for women (Hata and Nakajima, 1985); maltitol, $0.30 \mathrm{~g} / \mathrm{kg} \mathrm{BW}$ (Niwa et al., 1981); and sorbitol, $0.17 \mathrm{~g} / \mathrm{kg} \mathrm{BW}$ for men and $0.24 \mathrm{~g} / \mathrm{kg} \mathrm{BW}$ for women (Oku and Okazaki, 1996). Compared to these indigestible carbohydrates, FS-2H is less likely to cause acute diarrhea after administration of a single dose. The mechanism of diarrhea induced by indigestible carbohydrate is that the unabsorbed carbohydrate in the upper part of the small intestine mostly reaches the large intestine, which results in an increase in the osmotic pressure in the intestinal tract and an increase in the body fluid transferred into the intestinal tract (Niwa et al., 1981). Because the osmotic pressure is regulated by the molar concentration of substances, the osmotic pressure increases with a decrease in the average molecular weight if the weight concentration remains the same. Therefore, the higher acute no-effect level of FS-2H for diarrhea than other indigestible carbohydrates mentioned above is considered to be related to the higher average molecular weight of FS-2H (ca. 2000) than fructooligosaccharide (ca. 520), maltitol (344), and sorbitol (182).

No dose-dependent gastrointestinal symptoms were observed, and all of these symptoms were mild and transient and recovered to normal without any treatment. These symptoms have been reported and occur after consumption of other indigestible carbohydrates (Kohmoto et al., 1992; Niwa et al., 1981; Oku and Okazaki, 1996; Satouchi et al., 1993). Consequently, the gastrointestinal symptoms are supposed to have no toxicological implication.

In conclusion, the present results indicate that FS$2 \mathrm{H}$ did not show mutagenicity, and acute and 90-day subchronic oral toxicity studies in rats showed no adverse effects on any of the parameters examined, therefore the $\mathrm{LD}_{50}$ of FS-2H in rats was estimated to be higher than $10 \mathrm{~g} / \mathrm{kg} \mathrm{BW}$ and NOAEL was $10 \mathrm{~g} / \mathrm{kg} \mathrm{BW}$ or more on the acute oral toxicity study and $5.0 \mathrm{~g} / \mathrm{kg} \mathrm{BW} /$ day or more on the 90-day subchronic repeated oral toxicity study in rats. The acute no-effect level of FS-2H for diarrhea was $0.8 \mathrm{~g} / \mathrm{kg}$ $\mathrm{BW}$ for men and more than $1.0 \mathrm{~g} / \mathrm{kg} \mathrm{BW}$ for women.

\section{REFERENCES}

Fuse, T., Kumagai, T. and Watanabe, T. (2002): Effect of cooked rice containing indigestible dextrin on postprandial blood glucose level and the safety of eating it in the long term. J. Nutritional Food, 5, 47-53.

Hamano, T., Nakashima, A., Ebihara, S. and Watanabe, Y. (2004): The effect of beverage containing indigestible dextrin on the defecation of healthy volunteers and its safety. J. Nutritional. Food, 7, 29-43.

Hata, Y. and Nakajima, K. (1985): Furakutoorigotou sesshu to ityoushoujou no kankei. (In Japanese) Geriat. Med., 23, 817-828

Hayashi, N., Ohga, H., Kishimoto, Y. and Tagami, H. (2006): Effects of resistant hydrogenated starch hydrolysate on postprandial blood glucose levels. J. Jpn. Soc. Nutr. Food Sci., 59, 247253

Kishimoto, Y., Wakabayashi, S. and Yuba, K. (2000): Effects of instant miso-soup containing indigestible dextrin on moderating the rise of postprandial blood glucose levels, and safety of longterm administration. J. Nutritional. Food, 3, 19-27

Kohmoto, T., Fukui, F., Takaku, H., Takai, Y., Watanabe, T., Hata, Y. and Nakazima, K. (1992): Isomarutoorigotou no ityoushoujou to haiben, benseijou ni oyobosu eikyou. (In Japanese) Jpn. J. 
Y. Yoshikawa et al.

Clin. Nutr., 80, 53-58.

Lupton, J.R., Coder, D.M., Jacobs, L.R. (1988): Long-term effects of fermentable fibers on rat colonic $\mathrm{pH}$ and epithelial cell cycle. J. Nutr., 118, 840-845.

Nakagawa, M., Ohkawara, M., Kitagawa, Y. and Matsumoto, T. (2003): The effect of the intake of green tea beverage containing indigestible dextrin on postprandial blood glucose level and the investigation of the safety at its long-term intake. J. Nutritional Food, 6, 81-88.

Niwa, H., Hikichi, N., Sakurai, E., Ueda, M. and Fukuse, G. (1981): Alteration of biogenic amines, serotonin, histamine and polyamines, in cases of diarrhea induced by sugar alcohols. J. Pharm. Soc. Jpn., 101, 567-574.

Noto, T., Oishi, Y., Fujihira, S., Matsumoto, M., Yoshizawa, K., Tsubota, K., Hashimoto, M. and Ohara, K. (1999): Spontaneous lesions in Crj:CD(SD)IGS versus in Jcl(SD) rats used in toxicity studies. -Histopathological findings-. CD(SD)IGS-1999, 23-28.

Ohkuma, K., Matsuda, I., Katta, Y. and Hanno, Y. (1990): Pyrolysis of starch and its digestibility by enzymes. -Characterization of indigestible dextrin-. Denpun Kagaku, 37, 107-114.

Oku, T., Yamada, K. and Hosoya, N. (1979): Effects of pullulan and cellulose on the gastrointestinal tract of rats. Eiyo to Shokuryo (J. Jap. Soc. Nutr. Food Sci.), 32, 235-241.

Oku, T., Konishi, F. and Hosoya, N. (1982): Biochemical and morphological changes of gastrointestinal tract by dietary fiber in rat. Nutr. Rep. Int., 26, 247-253.

Oku, T. and Okazaki, M. (1996): Laxative threshold of sugar alcohol erythritol in human subjects. Nutr. Res., 16, 577-589.

Osada, T., Ebihara, S., Sakano, K. and Nakajo, M. (2011): Kangen- nanshoukasei dekisutorin haigou tei-tanpakusitu beihan no yuukousei (toutaisha oyobi jinkinou) to anzensei. (In Japanese) Jpn. J. Clin. Nutr., 118, 307-311.

Sakata, T. (1987): Stimulatory effect of short-chain fatty acids on epithelial cell proliferation in the rat intestine: a possible explanation for trophic effects of fermentable fibre, gut microbes and luminal trophic factors. Br. J. Nutr., 58, 95-103.

Satouchi, M., Wakabayashi, S., Ohkuma, K., Fujiwara, K. and Matsuoka, A. (1993): Effects of indigestible dextrin on bowel movements. Jpn. J. Nutr., 51, 31-37.

Tagami, H., Kishimoto, Y., Miyazato, S., Kitagawa, M., Hayashi, N., Yoshikawa, Y., Oga, H., Yamada, T. and Nishibata, T., (2012): Energy value evaluation of hydrogenated resistant maltodextrin. Biosci. Biotechnol. Biochem., 76, 1828-1834.

Wakabayashi, S., Satouchi, M., Nogami, Y., Ohkuma, K. and Matsuoka, A. (1991): Effect of indigestible dextrin on cholesterol metabolism in rat. J. Jpn. Soc. Nutr. Food Sci., 44, 471-478.

Wakabayashi, S., Satouchi, M., Ueda, Y. and Ohkuma, K. (1992): Acute toxicity and mutagenicity studies of indigestible dextrin, and its effect on bowel movement of the rat. Shokuei-shi, 33, 557-562.

Yoshioka, M., Shimomura, Y. and Suzuki, M. (1994): Dietary polydextrose affects the large intestine in rats. J. Nutr., 124, 539-547.

Yuasa, M., Yasue, M., Ikeda, M., Shinoda, Y., Sato, K. and Kondo, A. (2004): The effect of tea beverages containing indigestible dextrin on postprandial blood glucose level after single intake and safety in continuous intake. J. Jpn. Council for Advanced Food Ingredients Res., 7, 83-93. 